\title{
Enantio- and Diastereoselective Synthesis of $\mathrm{N}$-Acetyl Dihydrotetrafibricin Methyl Ester
}

\author{
Philippe Nuhant and William R. Roush ${ }^{*}$ \\ Department of Chemistry, Scripps Florida, Jupiter, Florida 33458
}

\begin{abstract}
A highly diastereoselective synthesis of $N$-acetyl dihydrotetrafibricin methyl ester (34) is described. The synthesis features three enantioselective double allylboration reactions, an intramolecular hydrosilylation/Tamao-Fleming oxidation sequence to establish seven of the hydroxy-bearing stereocenters of $\mathbf{3 4}$. Especially noteworthy is the fragment assembly double allyboration reaction of $\mathbf{2}$ and $\mathbf{7}$ with reagent $\mathbf{3}$ that provides the advanced intermediate $\mathbf{6}$ with $>20: 1$ diastereoselectivity.
\end{abstract}

Tetrafibricin (1) (Figure 1) is a structurally unique natural product isolated from Streptomyces neyagawaensis ${ }^{1}$ that displays potent anti-aggregation properties against human platelets by blocking the glycoprotein (GP) IIb/IIIa receptor on the platelet surface, which is important for blood clotting. ${ }^{2}$ The stereochemistry of tetrafibricin was assigned by Kishi based on ${ }^{1} \mathrm{H}$ NMR data-base technology. ${ }^{3}$ Studies directed towards the synthesis of tetrafibricin have been described by Cossy, ${ }^{4}$ Curran, ${ }^{5}$ Friestad, ${ }^{6}$ Krische ${ }^{7}$ and our group. ${ }^{8}$ However a total synthesis of tetrafibricin has not been reported, which is necessary to confirm Kishi's relative and absolute stereochemical assignment.

Our strategy for the synthesis of tetrafibricin is outlined in Scheme 1. The synthesis was designed with the intent to apply the double allylboration methodology developed in our laboratory ${ }^{8,9}$ to establish several of the 1,5-diol relationships in the natural product. We initially envisioned that $\mathbf{1}$ would be accessed by a late stage, fragment assembly double allylboration reaction of aldehydes $\mathbf{4}^{8 \mathrm{a}}$ and $\mathbf{2}^{8 \mathrm{c}, \mathrm{d}}$ with the first generation reagent 3 . $^{9}$ As it turns out, several attempts ${ }^{8 \mathrm{~b}}$ at this coupling with these and related intermediates proceeded in low yield, which we ultimately traced to the instability of 4. Curran's group reported similar issues in their attempts to effect a Kociensky-Julia olefination reaction with an analog of $4{ }^{5 \mathrm{c}}$ These observation prompted us to reexamine our synthesis and to plan to install the polyene unit at the late stage from the Horner-Wadsworth-Emmons reaction between the known phosphonate $5^{8 \mathrm{a}}$ and the $\mathrm{C}(9)-\mathrm{C}(40)$ aldehyde $\mathbf{6}$. We envisaged that 6 could be obtained in a highly convergent way from a $(E)-1,5$-anti double allylboration reaction ${ }^{9}$ of aldehydes $\mathbf{2}$ and $\mathbf{7}$ with 1,3-bifunctional allylborane $\mathbf{3}$. Key aldehyde intermediate 2 would be accessed by applying an $(E)$-1,5-syn double allylboration reaction of aldehydes $\mathbf{8}$ and $\mathbf{1 0}$ and the 1,3-bifunctional allylborane $\mathbf{9} .{ }^{8 c, d}$ Aldehyde fragment $\mathbf{7}$ would be derived from 1,5-(Z)-diol $\mathbf{1 1}$ by an intramolecular hydrosilylation/Tamao-Fleming

*Corresponding Author, roush@scripps.edu.

ASSOCIATED CONTENT

Supporting Information

Experimental procedures and spectroscopic data for all new compounds. This material is available free of charge via the Internet at http://pubs.acs.org.

Notes

The authors declare no competing financial interests. 
oxidation sequence. ${ }^{10,11}$ Finally, 1,5-diol $\mathbf{1 1}$ would be obtained from a third double allylboration reaction, in this case using the 1,3-bifunctional allylborane $\mathbf{1 3}^{9}$ to couple aldehydes 12 and $\mathbf{1 4}$.

The synthesis of aldehyde $\mathbf{2}$ proceeded from the previously synthesized carbamate intermediate $17^{8 c, d}$ (as briefly summarized at the beginning of Scheme 2). Deprotection of the PMB ether was accomplished by using DDQ, which provided 18 in $80 \%$ yield. The tertbutyl carbamate (Boc) unit was replaced by an allyl carbamate to facilitate deprotection chemistry at the end of the synthesis. Thus, treatment of $\mathbf{1 8}$ with TMSOTf and 2,6-lutidine in $\mathrm{CH}_{2} \mathrm{Cl}_{2}$ resulted in protection of the primary alcohol as a TMS ether and cleavage of the Boc group. The primary amine was then protected by treatment with allyl chloroformate, and the TMS ether was removed in acidic media to give 19 in $70 \%$ over three steps. Finally oxidation of the primary alcohol with Dess-Martin periodinane ${ }^{12}$ gave the targeted C(23)C(40) aldehyde $\mathbf{2}$ in $98 \%$ yield (Scheme 2).

The synthesis of the $\mathrm{C}(9)-\mathrm{C}(19)$ aldehyde fragment $\mathbf{7}$ is presented in Scheme 3. Treatment of aldehyde 12 with bifunctional $(E)$-allylborane 13, which was generated in situ via hydroboration of allene $\mathbf{2 1}$ with ( $d$-diisopinocampheyl)borane $\left({ }^{d} \mathrm{Ipc}\right)_{2} \mathrm{BH},{ }^{9}$ afforded a $\beta$ hydroxy allylboronate intermediate, which was isolated and then protected by treatment with TBSOTf, thereby providing allylboronate $\mathbf{2 2}$ in $62 \%$ yield over two steps. Treatment of $\mathbf{2 2}$ with the partner aldehyde $14^{8 \mathrm{a}}$ provided homoallylic alcohol $\mathbf{1 1}$ in 15:1 d.r. and 79\% yield. The latter intermediate was treated with 1,1,3,3-tetramethyldisilazane, and the crude alkoxysilane was subjected to a hydrosilylation-Fleming/Tamao oxidation sequence ${ }^{10,11}$ using Karstedt's catalyst (platinum(0)-1,3-divinyl-1,1,3,3-tetramethyl-dioloxane) ${ }^{13}$ for the hydrosilylation step. This two-pot sequence afforded alcohol 23 in $85 \%$ yield. Treatment of diol 23 with carbonyldiimidazole afforded cyclic carbonate $\mathbf{2 4}$ in $85 \%$ yield. Finally, cleavage of the DMTr ether under acidic conditions ${ }^{14}$ followed by oxidation of the primary alcohol with Dess-Martin periodinane ${ }^{12}$ furnished aldehyde 7 in $69 \%$ yield. The absolute configuration of the $\mathrm{C}(13)$-hydroxyl group of $\mathbf{1 1}$ was assigned by using the Mosher ester method. ${ }^{15}$ The absolute and relative configuration of $\mathrm{C}(17)$-hydroxyl group was deduced by analogy to the previously reported C(19)-TBDPS ether. ${ }^{8 a, b}$ The 1,3-syn diol stereochemistry of $\mathbf{2 3}$ was determined by using Rychnovsky's acetonide analysis. ${ }^{16}$

Sequential treatment of the 1,3-bifunctional allylborane $\mathbf{3}$, generated in situ from hydroboration of allenylboronate $\mathbf{2 5}$ with $\left(\mathrm{Ipc}_{2}\right)_{2} \mathrm{BH},{ }^{9 \mathrm{a}}$ with aldehydes $\mathbf{7}(0.54$ equiv.) and $\mathbf{2}$ (1.0 equiv.) provided the $\mathrm{C}(9)-\mathrm{C}(40)$ fragment 6 in $68 \%$ yield, with exceptional diastereoselectivity (>20:1) and $E / Z$ ratio (>20:1). Protection of the 1,5-diol unit using $\mathrm{TBSCl}$ and imidazole followed by oxidative cleavage ${ }^{17}$ of the 3,4-dimethoxybenzyl ether gave primary alcohol $\mathbf{2 7}$ in $83 \%$ yield over two steps. Oxidation of the primary alcohol by using Dess-Martin periodinane ${ }^{12}$ followed by Horner-Wadsworth-Emmons reaction of the resulting aldehyde with phosphonate $\mathbf{2 8}$ yielded $\mathrm{C}(1)-\mathrm{C}(40)$ fragment $\mathbf{2 9}$ in $68 \%$ yield over the two steps. Cleavage of the cyclic carbonate (allyl alcohol, $\mathrm{K}_{2} \mathrm{CO}_{3}$ ) followed by selective monoprotection of the $\mathrm{C}(15)$ alcohol using TBSOTf gave $\mathbf{3 0}$ in $70 \%$ yield. Finally, oxidation of the secondary alcohol 30, removal of both the allyl ester and allyl carbamate (Alloc) groups, ${ }^{18}$ and global cleavage of the TBS ethers provided a small sample of impure material that we tentatively identified as tetrafibricin (1) by LCMS and ${ }^{1} \mathrm{H}$ NMR data.

The ${ }^{1} \mathrm{H}$ NMR data that we obtained for the impure sample of synthetic tetrafibricin (1) were consistent with data for the natural product published in the isolation paper, ${ }^{1 \mathrm{a}}$ however all attempts to purify the sample led to decomposition. Tetrafibricin is reported to be highly unstable in the isolation paper, ${ }^{1}$ and comments about its instability also appear in Kishi's structure elucidation manuscript. ${ }^{3}$ Therefore, our attention shifted to the synthesis of the 
more stable $N$-acetyl dihydrotetrafibricin methyl ester (34), ${ }^{1 \mathrm{~b}}$ which served as the focus of Kishi's stereochemistry assignment owing to the instability of the natural product. ${ }^{3}$

The synthesis of $\mathbf{3 4}$ proceeded from the $\mathrm{C}(9)-\mathrm{C}(40)$ fragment $\mathbf{2 6}$ as follows. Replacement of the $\mathrm{N}$-Alloc by an $\mathrm{N}$-acetyl group was accomplished in a one-pot operation ( $81 \%$ yield) by treating 26 with $\mathrm{Bu}_{3} \mathrm{SnH}$ and $\mathrm{Pd}\left(\mathrm{PPh}_{3}\right)_{4}$ followed by addition of acetic anhydride and $\mathrm{Et}_{3} \mathrm{~N}^{18}$ The 3,4-dimethoxybenzyl ether unit of $\mathbf{3 1}$ was cleaved by treatment with $\mathrm{DDQ}^{17}$ to give primary alcohol $\mathbf{3 2}$ in $92 \%$ yield. Oxidation of $\mathbf{3 2}$ using the Dess-Martin periodinane ${ }^{12}$ followed by Horner-Wadsworth-Emmons olefination of the aldehyde with phosphonate $5^{9}$ provided the advanced C(1)-C(40) intermediate $\mathbf{3 3}$ in 59\% yield over two steps. Finally, cleavage of the carbonate unit $\left(\mathrm{MeOH}, \mathrm{K}_{2} \mathrm{CO}_{3}\right)$ with concomitant trans-esterification of the ester, followed by deprotection of the nine TBS ethers with excess $\mathrm{Et}_{3} \mathrm{~N} \cdot 3 \mathrm{HF}$ provided $N$ acetyl dihydrotetrafibricin methyl ester (34) in 59\% yield over the final two steps. The ${ }^{1} \mathrm{H}$ and ${ }^{13} \mathrm{C}$ NMR data obtained for 34 were in complete agreement with published data, and with NMR spectra (of a mixture of $\mathbf{3 4}$ and the C(13)-epimer) provided by Prof. Kishi.

In conclusion, attempts to complete the total synthesis of tetrafibricin (1) have been compromised by instability of the natural product, which prompted us to synthesize the more stable analog $N$-acetyl dihydrotetrafibricin methyl ester (34). The longest linear sequence in the synthesis is 21 steps from 4-azidobutanal (15), and proceeds with an overall yield of $2 \%$. This work validates Kishi's stereochemical assignment of tetrafibricin, and illustrates the utility of the double allylboration reaction technology developed in our group for use in the highly stereocontrolled and convergent synthesis of stereochemically complex natural products.

\section{Supplementary Material}

Refer to Web version on PubMed Central for supplementary material.

\section{Acknowledgments}

We thank the National Institutes of Health (GM038436) for support of this research. We sincerely thank Dr. Ricardo Lira who performed exploratory studies on the coupling of $\mathbf{2}$ and $\mathbf{4}$, and Professor Yoshito Kishi who provided copies of the ${ }^{1} \mathrm{H}$ and ${ }^{13} \mathrm{C}$ NMR spectra of a 2:1 mixture of $\mathbf{3 4}$ and its $\mathrm{C}(13)$-epimer for comparison. We are also grateful to Professor Glenn Micalizio helpful suggestions and comments on this work.

\section{REFERENCES}

1. (a) Kamiyama T, Umino T, Fujisaki N, Fujimori K, Satoh T, Yamashita Y, Ohshima S, Watanabe J, Yokose K. J. Antibiot. 1993; 46:1039-1046. [PubMed: 8360097] (b) Kamiyama T, Itezono Y, Umino T, Satoh T, Nakayama N, Yokose K. J. Antibiot. 1993; 46:1047-1054. [PubMed: 8360098]

2. (a) Satoh T, Yamashita Y, Kamiyama T, Watanabe J, Steiner B, Hadvary P, Arisawa M. Thromb. Res. 1993; 72:389-400. [PubMed: 8303682] (b) Satoh T, Yamashita Y, Kamiyama T, Arisawa M. Thromb. Res. 1993; 72:401-412. [PubMed: 8303683] (c) Satoh T, Kouns WC, Yamashita Y, Maiyama T, Steiner B. Biochem. J. 1994; 301:785-791. [PubMed: 7519850] (d) Satoh T, Kouns WC, Yamashita Y, Kamiyama T, Steiner B. Biochem. Biophys. Res. Commun. 1994; 204:325-332. [PubMed: 7524499]

3. Kobayashi Y, Czechtizky W, Kishi Y. Org. Lett. 2003; 5:93-96. [PubMed: 12509899]

4. BouzBouz S, Cossy J. Org. Lett. 2004; 6:3469-3472. [PubMed: 15387525]

5. (a) Gudipati V, Bajpai R, Curran DP. Collect. Czech. Chem. Commun. 2009; 74:771-783.(b) Zhang K, Gudipati V, Curran DP. Synlett. 2010:667-671. [PubMed: 20686632] (c) Gudipati V, Curran DP. Tetrahedron Lett. 2011; 52:2254-2257. [PubMed: 21603053]

6. Friestad GK, Sreenilayam G. Org. Lett. 2010; 12:5016-5019. [PubMed: 20939544]

7. Kumpulainen ETT, Kang B, Krische MJ. Org. Lett. 2011; 13:2484-2487. [PubMed: 21469726] 
8. (a) Lira R, Roush WR. Org. Lett. 2007; 9:533-536. [PubMed: 17249805] (b) Lira, R. PhD Thesis. The Scripps Research Institute; 2008 May. (c) Kister J, Nuhant P, Lira R, Sorg A, Roush WR. Org. Lett. 2011; 13:1868-1871. [PubMed: 21375316] (d) Nuhant P, Kister J, Lira R, Sorg A, Roush WR. Tetrahedron. 2011; 67:6497-6512. [PubMed: 21857752]

9. (a) Flamme EM, Roush WR. J. Am. Chem. Soc. 2002; 124:13644-13645. [PubMed: 12431072] (b) Flamme EM, Roush WR. Org. Lett. 2005; 7:1411-1414. [PubMed: 15787519]

10. (a) Tamao K, Nakajima T, Sumiya R, Arai H, Higuchi N, Ito Y. J. Am. Chem. Soc. 1986; 108:6090-6093. [PubMed: 22175405] (b) Tamao K, Nakagawa Y, Arai H, Higuchi N, Ito Y. J. Am. Chem. Soc. 1988; 110:3712-3714.(c) Young DGJ, Hale MR, Hoveyda AH. Tetrahedron Lett. 1996; 37:827-830.(d) Hoveyda AH, Hale MR. J. Org. Chem. 1992; 57:1643-1645.(d) Denmark SE, Forbes DC. Tetrahedron Lett. 1992; 33:5037-5040.

11. Li F, Roush WR. Org. Lett. . 2009; 11:2932-2935. [PubMed: 19507846]

12. Dess DB, Martin JC. J. Org. Chem. 1983; 48:4155-4156.

13. (a) Hitchcock PB, Lappert MF, Warhurst JW. Angew. Chem. Int. Ed. Engl. 1991; 30:438-440.(b) Faglioni F, Blanco M, Goddard WA, Sauners D. J. Phys. Chem. B. 2002; 106:1714-1721.

14. Matysiak S, Böldicke T, Tegge W, Frank R. Tetrahedron Lett. 1998; 39:1733-1734.

15. (a) Dale JA, Mosher HS. J. Am. Chem. Soc. 1973; 95:512-519.(b) Ohtani I, Kusumi T, Kashman Y, Kakisawa H. J. Am. Chem. Soc. 1991; 113:4092-4096.

16. Rychnovsky SD, Rogers B, Yang G. J. Org. Chem. 1993; 58:3511-3515.

17. Horita K, Yoshioka T, Tanaka T, Oikawa Y, Yonemitsu O. Tetrahedron. 1986; 42:3021-3028.

18. Guibe F. Tetrahedron. 1998; 54:2967-3042. 


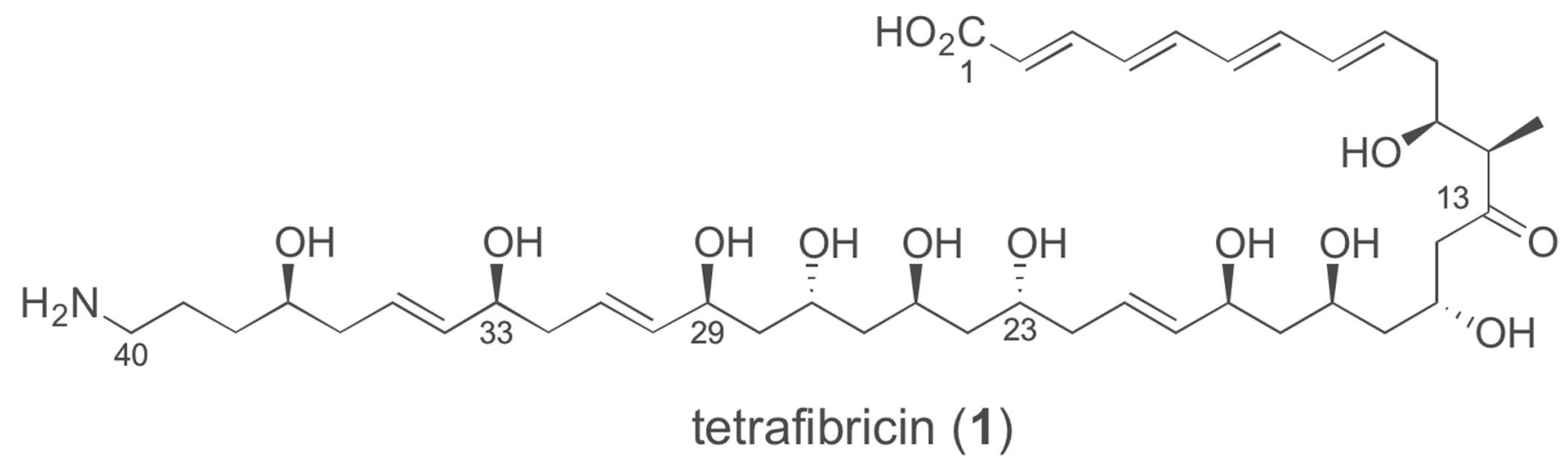

Figure 1.

Structure of Tetrafibricin (1) 

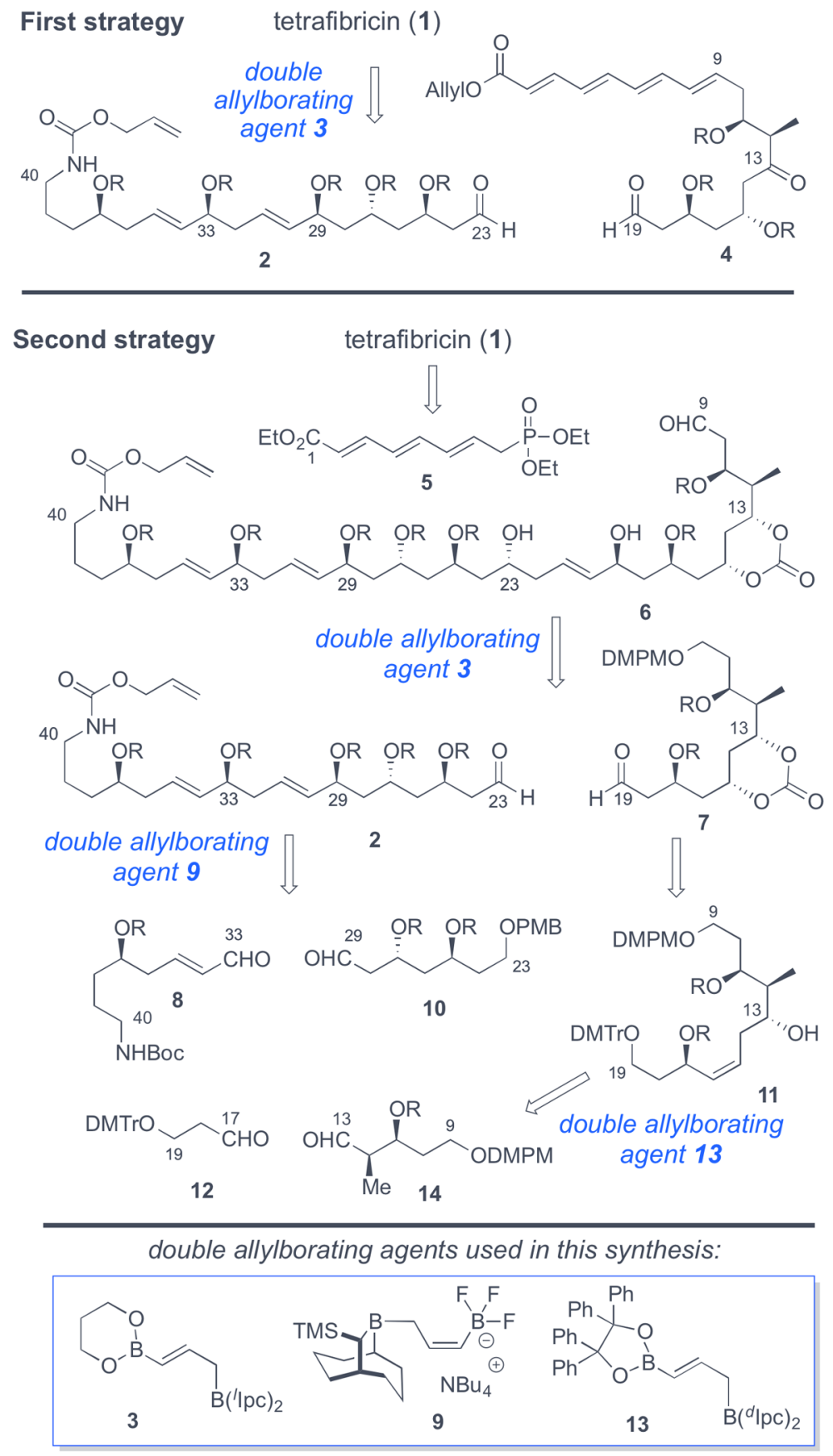

Scheme 1.

Retrosynthetic analysis of tetrafibricin $(\mathrm{R}=\mathrm{TBS})$ 
<smiles>NCCCC=O</smiles>

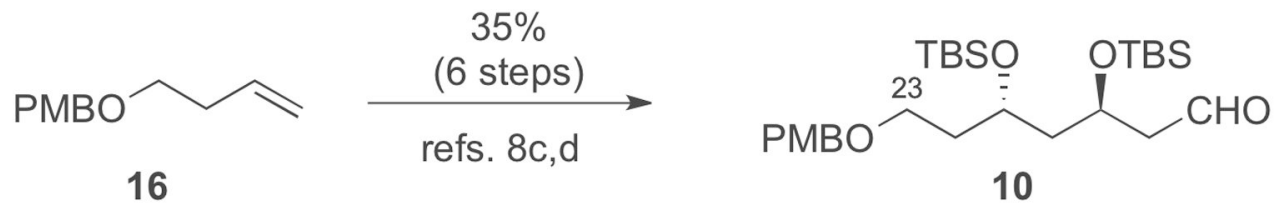

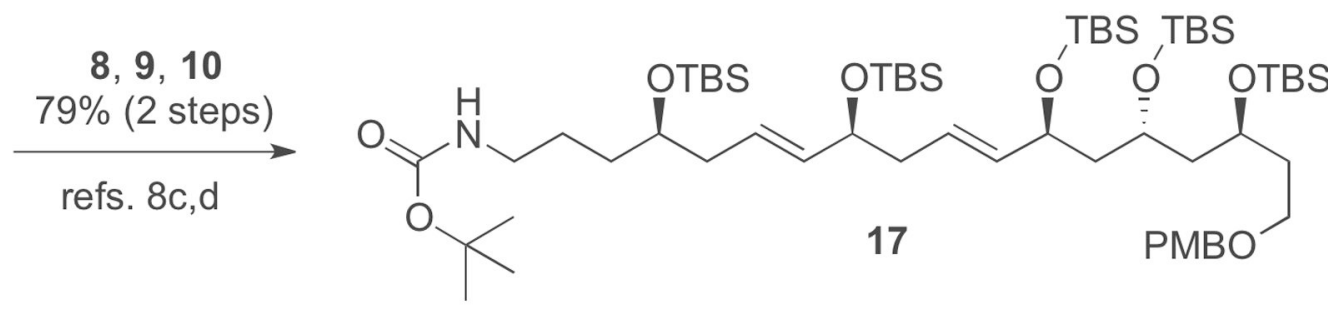<smiles>[B-]O[C@@H]([O-])/C=C/C[C@@H]([OH2+])CCCNC(=O)OC(C)(C)C</smiles>

1) TMSOTf, 2,6-lutidine

2) allyl-OCOCl $\mathrm{Et}_{3} \mathrm{~N}, \mathrm{CH}_{2} \mathrm{Cl}_{2}$

3) $\mathrm{AcOH}-\mathrm{H}_{2} \mathrm{O}-\mathrm{THF}$

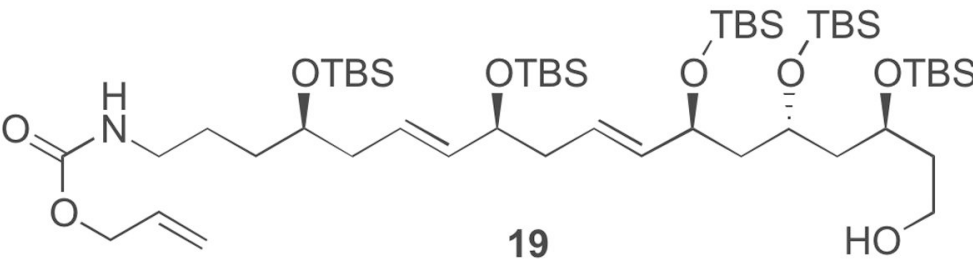
$70 \%$

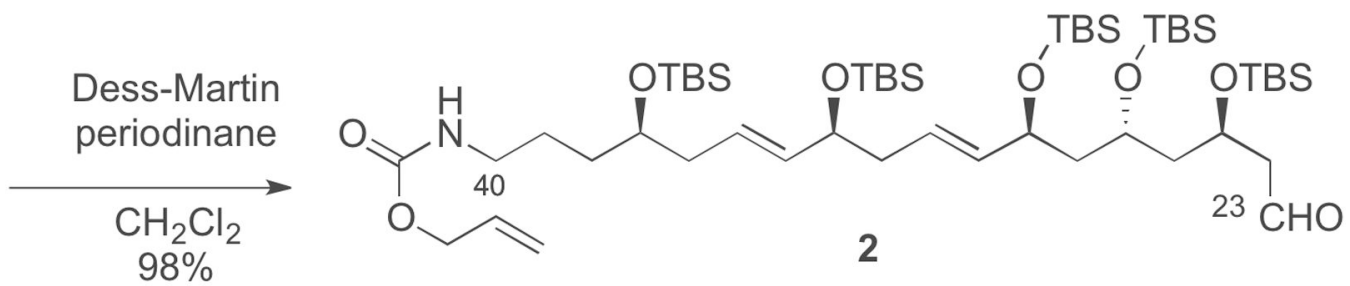

Scheme 2.

Synthesis of C(23)-C(40) Aldehyde 2 


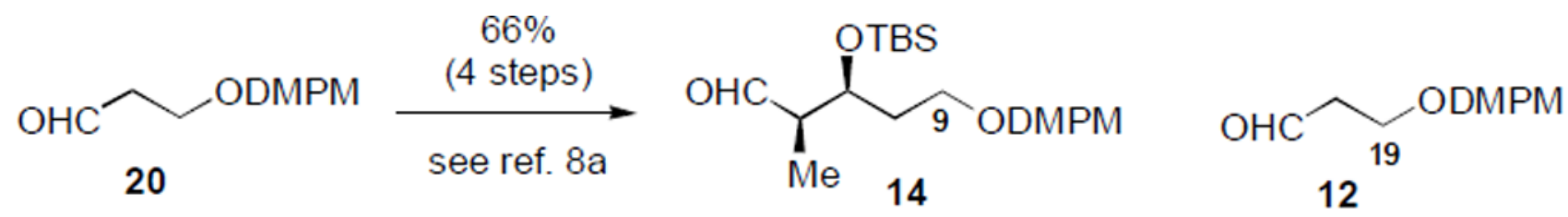

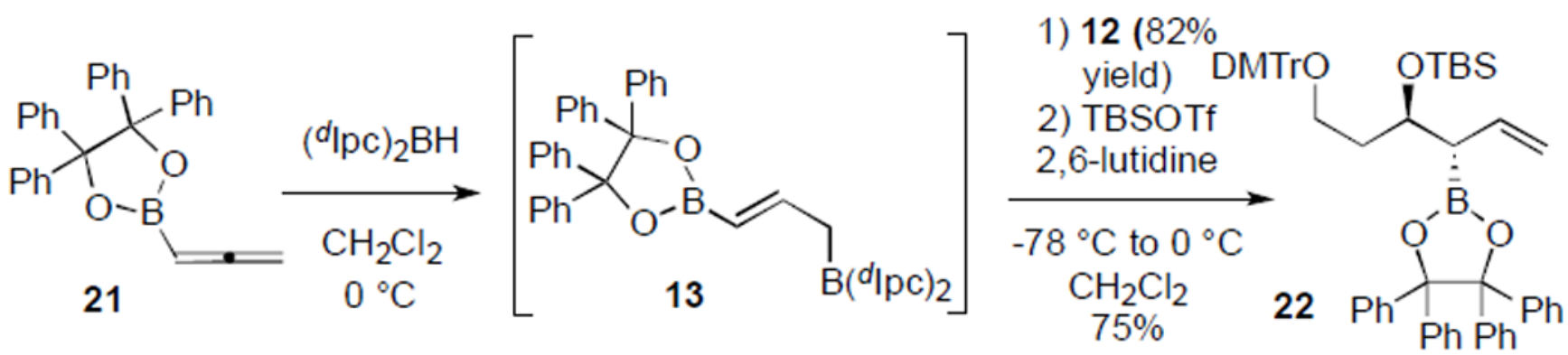

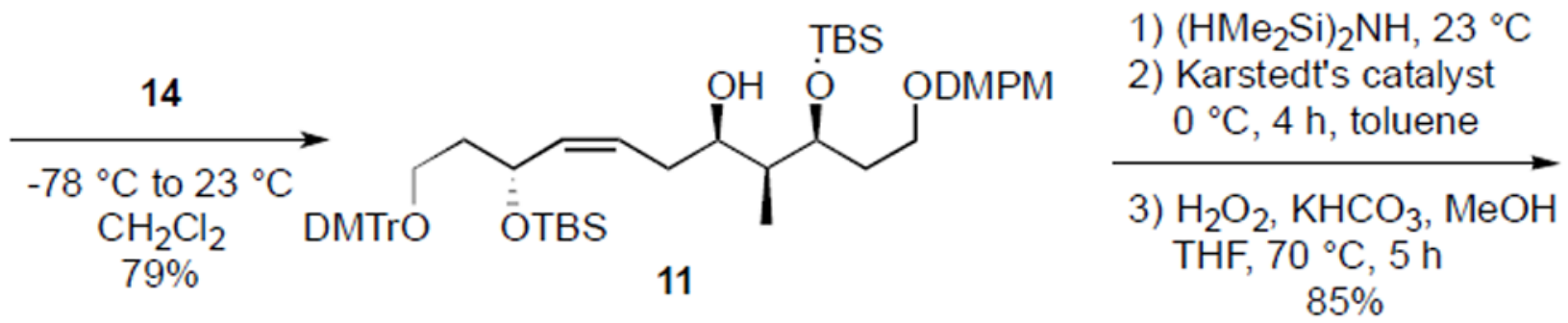

1) $\mathrm{AcOH}$, trifluoroethanol $\mathrm{CH}_{2} \mathrm{Cl}_{2}, 77 \%$

2) Dess-Martin periodinane $89 \%$

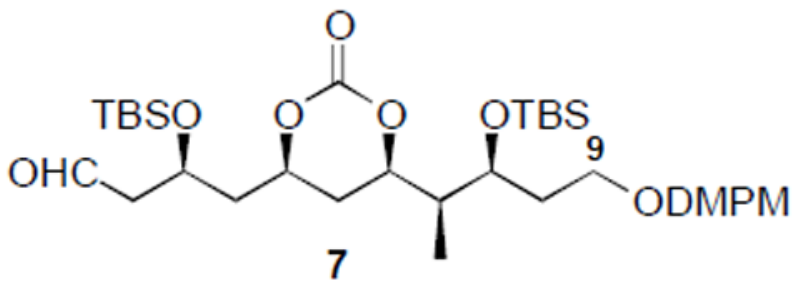

Scheme 3.

Synthesis of C(9)-C(19) Aldehyde 7 

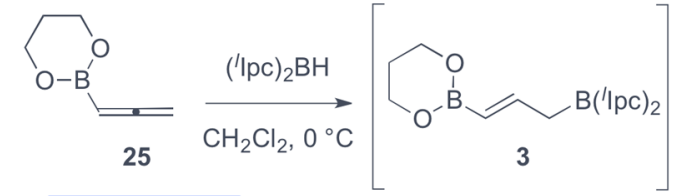

$\begin{gathered}7,-78{ }^{\circ} \mathrm{C}, 5 \mathrm{~h} \\ \text { then }\end{gathered}$
$\underset{\begin{array}{c}2,-78 \text { to } 23^{\circ} \mathrm{C} \\ 68 \%\end{array}}{\longrightarrow}$
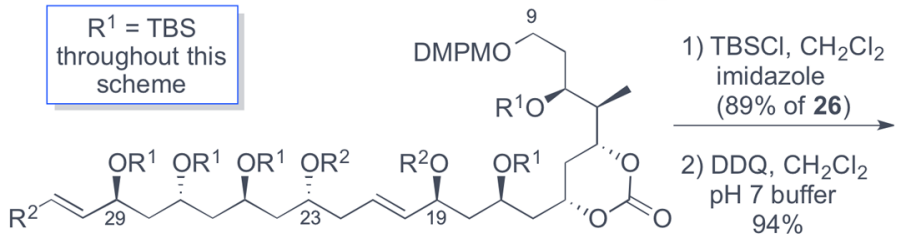

$94 \%$

$$
\begin{aligned}
\text { 6, } R^{2} & =H \\
26, R^{2} & =T B S
\end{aligned}
$$

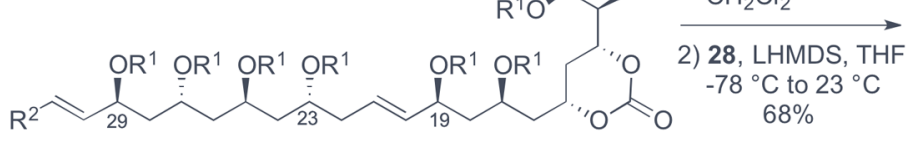

27

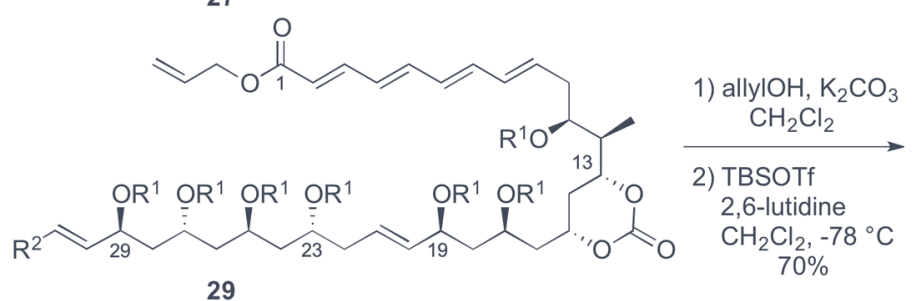

29

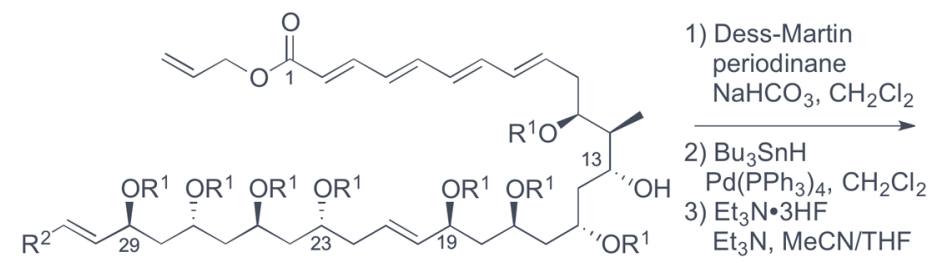

30

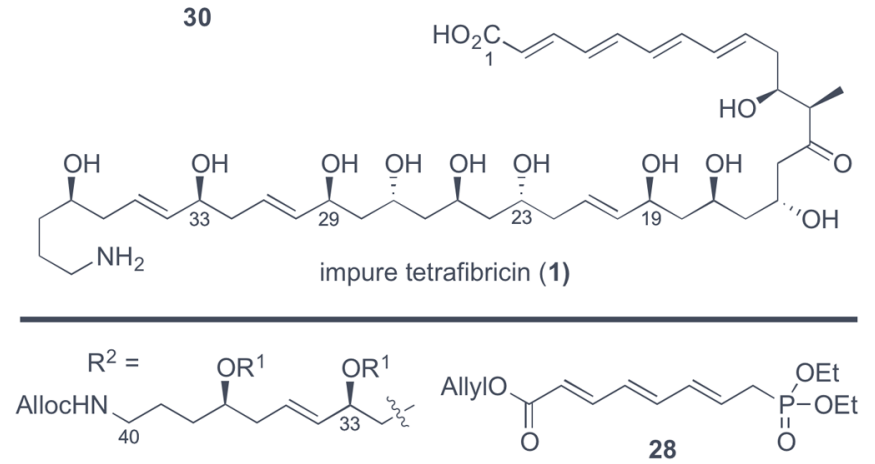

Scheme 4.

Attempted Synthesis of Tetrafibricin, $1\left(\mathrm{R}^{1}=\mathrm{TBS}\right)$ 


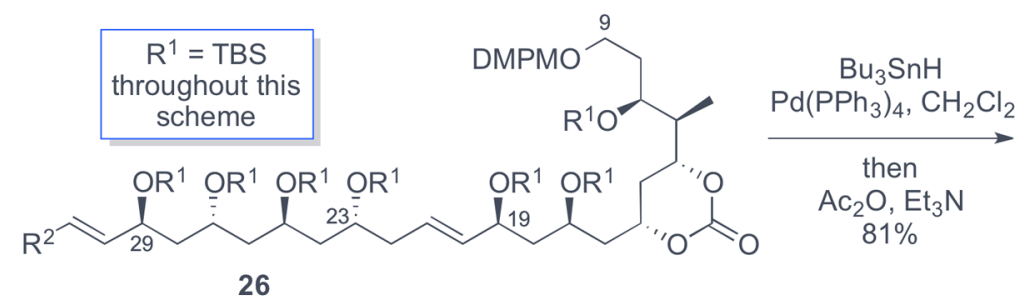

26

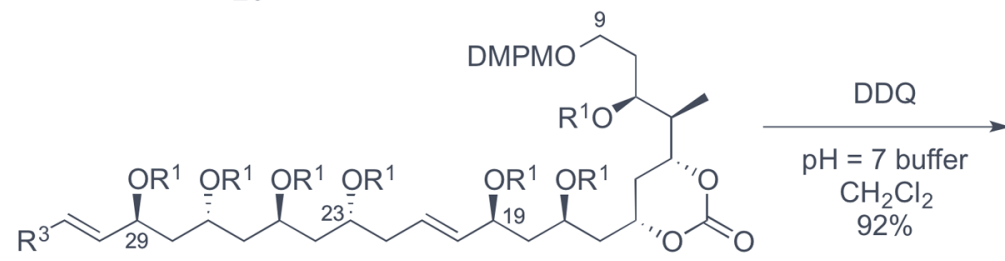

31

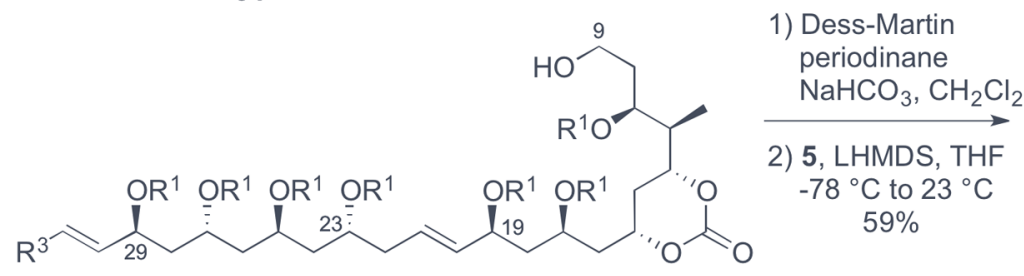

32<smiles>[R10]C(CC)CC=CC=CC=CC=CC(=O)OCC</smiles>

1) $\mathrm{MeOH}, \mathrm{K}_{2} \mathrm{CO}_{3}$ $\mathrm{CH}_{2} \mathrm{Cl}_{2}$

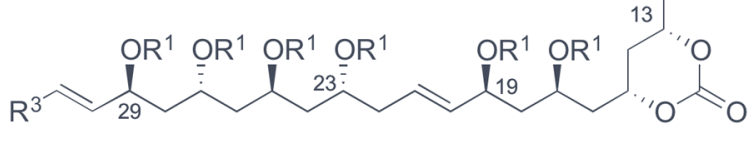

2) $\mathrm{Et}_{3} \mathrm{~N} \cdot 3 \mathrm{HF}$ $\mathrm{Et}_{3} \mathrm{~N}$, $\mathrm{CH}_{3} \mathrm{CN} / \mathrm{THF}$

33 $59 \%$

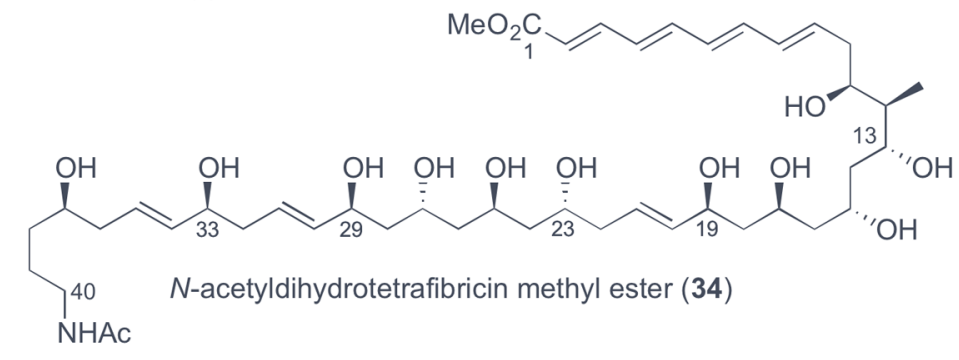

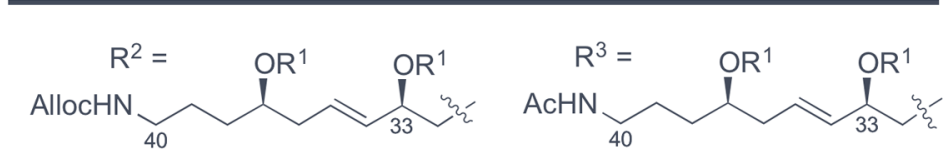

Scheme 5.

Synthesis of $N$-Acetyl Dihydrotetrafibricin Methyl Ester (34) 